\title{
O COSMOPOLITISMO POR UMA INTERNACIONALIZAÇÃO DO DIREITO: O FORTALECIMENTO RECÍPROCO DO GLOBAL E DO NACIONAL POR MEIO DA PROTEÇÃO DO DIREITO HUMANO À INFORMAÇÃO
}

\begin{abstract}
Cosmopolitanism for a globalization of the law: the cross of strengthening of national and global through the protection of human right to information
\end{abstract}

\section{Francieli Puntel Raminelli}

Mestranda da Universidade Federal de Santa Maria, no programa de pós-graduação em Direito, com ênfase em Direitos Emergentes da Sociedade Global. Graduada em Direito pela mesma Instituição (2013) Membro do Conselho Nacional de Pesquisa e Pós-graduação em Direito (CONPEDI). Bolsista CAPES. Email:francieli.raminelli@gmail.com

\begin{abstract}
Rafael Santos de Oliveira Doutor em Direito pela Universidade Federal de Santa Catarina (2010). Mestre em Integração Latino-Americana (Direito da Integração) pela Universidade Federal de Santa Maria (2005) e Graduado em Direito pela Universidade Federal de Santa Maria (2003). Atualmente é Professor Adjunto II no Departamento de Direito da Universidade Federal de Santa Maria (UFSM), em regime de dedicação exclusiva e no Programa de Pós-graduação em Direito da UFSM (Mestrado).
\end{abstract}

Recebido em: 13.05.2014

Aprovado em: 18.08.2015

DOI:10.5585/Rdb.v10i5.161

\section{Resumo}

O ideal cosmopolita, apesar de muito antigo, ainda hoje encontra espaço quando se trata da busca da internacionalização de direitos. A necessidade de uma abertura ao diferente, mais do que nunca, transformou-se em uma realidade diante da grande interpenetração de fronteiras e culturas, o que se percebe principalmente no contexto da sociedade informacional. Por este motivo, a proteção de direitos humanos fundamentais requer um consenso mundial, o que também necessita de estados fortalecidos internamente. Para isto, é necessária a democracia plena, que é respaldada pelo direito à informação dos cidadãos. Por meio do método de abordagem de- 
dutivo e das técnicas de pesquisa documental e bibliográfica, este trabalho objetiva relacionar o cosmopolitismo às atuais necessidades globais. Conclui-se que o ideal cosmopolita, ainda que contrarie a atual "sede" de instantaneidade de informações, por ter nascido há milhares de anos, consiste em uma interessante alternativa para a resolução de temas relativos a toda a humanidade.

Palavras-Chave: Cosmopolitismo. Internacionalização do direito. Direitos humanos. Direito à informação. Democracia.

\section{Abstract}

Despite being very old, cosmopolitan ideal still finds room when it comes to the pursuit of internationalization of rights. The need for openness to different, more than ever, has become a reality before the great interpenetration borders and cultures, which can be seen mainly in the context of the information society. For this reason, the protection of fundamental human rights requires a global consensus, which also require strengthened internal states. For this, a full democracy, which is supported by the right to information of citizens, is required. Through the method of deductive approach and the techniques of documentary and bibliographic research, this work aims cosmopolitanism relate to current global needs. We conclude that the cosmopolitan ideal, yet contrary to current "thirst" for information immediacy, because he was born thousands of years ago, is an interesting alternative for resolving issues related to all mankind.

Keywords: Cosmopolitanism. International law. Human rights. Right to information; democracy.

\section{Introdução}

A ideia de que o mundo atual possa alcançar um consenso ou, ao menos, encontrar soluções coletivas para problemas que dizem respeito a toda a humanidade não é e nunca foi um absurdo. De fato, ao longo do tempo, as interpenetrações e influências recíprocas entre países somente aumentaram, sendo que hoje é impossível que um Estado exista sem relacionar-se com outros. Neste contexto, o advento da Internet auxiliou a reduzir distâncias e aproximar pessoas, o que remete ainda mais a necessidade de manutenção de relações entre países.

O ideal cosmopolita, iniciado há milênios, busca esta abertura, pela qual os Estados Nacionais possam existir e resistir, construindo pontes de diálogos entre si e fortalecendo-se reciprocamente. Quando se tratam de questões referentes a todos os governos, ainda, tem-se que esta inter-relação torna-se mais essencial, principalmen- 
te pelo fato de que ordens jurídicas necessitam, de alguma forma, trabalhar juntas.

Neste contexto, uma questão emerge: por meio dos aportes teóricos do cosmopolitismo, é possível conceber o fortalecimento de direitos humanos que também garantem Estados Nacionais Democráticos, em especial, o direito à informação? De que forma se relacionam estas duas esferas, global e local, e como se dá a ligação entre elas e entre as diferentes ordens jurídicas mundiais?

Objetiva-se, por meio do método de abordagem dedutivo e da utilização das técnicas de pesquisa documental e bibliográfica, encontrar de que forma o projeto cosmopolita se insere na atual sociedade informacional e se pode colaborar para a construção de um novo constitucionalismo ou regulação mundial, em que os direitos humanos sejam tutelados de forma eficaz e auxiliem no fortalecimento da relação global-local.

Para tanto, este artigo encontra-se dividido em duas partes. A primeira, que apresentará o cosmopolitismo desde seus primórdios, com os cínicos na Grécia antiga até os mais recentes tratamentos doutrinários; e a segunda, que, por meio de novas alternativas apresentadas por Marcelo Neves, busca uma alternativa para que o diálogo entre os diversos países seja efetivado, principalmente para a proteção de direitos humanos, como é o caso do direito à informação.

\section{DO NACIONAL AO GLOBAL: O COSMOPOLITISMO PELA CONSTRU- ÇÃO DE UMA SOCIEDADE MUNDIALIZADA}

O estudo da possibilidade de uma internacionalização do direito, por meio de entendimentos comuns entre as nações mundiais perpassa a ideia, milenar, do pertencimento do cidadão a algo maior que seu próprio Estado. Neste sentido, o cosmopolitismo deve ser repensado, desde suas raízes na Grécia antiga até seu atual entendimento por teóricos e estudiosos do tema.

Assim, nos próximos tópicos serão apresentados os conceitos de cosmopolitismo desde sua origem, com os cínicos gregos e Immanuel Kant, considerados para este estudo como filósofos antigos devido a distância que se encontram da atual modernidade, até o presente, com a apresentação de teorias de alguns dos atuais pensadores do tema, entre eles David Held, Ulrich Beck, Kwame Anthony Appiah e Otfried Hoffe.

\subsection{DO COSMOPOLITISMO DOS ANTIGOS}

A ideia inicial do conceito de cosmopolitismo possui raízes na antiguidade, ainda durante a Grécia Antiga. Seus primeiros contornos foram iniciados pelos cínicos, tidos como homens inteligentes que "rejeitaram a sutileza intelectual em favor da simplicidade e expressaram essa simplicidade de formas paradoxais e lúdicas que, embora muitas vezes parecessem estúpidas, de fato não o eram" (MOLES, 2007, p. 
121). Como seu primeiro representante, pode-se citar Diógenes ${ }^{1}$, apenas melhor conhecido, entretanto, a partir da idade média por meio de literaturas latinas (de pagãos e, em menor número, cristãos) e árabes (MATTON, 2007, p. 265).

A ideia de que os cínicos fossem ignorantes ou, no mínimo, rudimentares, se expressa no simples comportamento que apresentavam perante a sociedade grega em sua época. Eles faziam em público coisas que as outras pessoas tomavam muito cuidado para esconder, desde alimentar-se até manter relações íntimas, sendo, por isto, relacionados a cães. Diógenes, como grande representante do grupo, morava em um barril, demonstrando total desapego aos bens materiais (MATTON, 2007, p. $286)^{2}$.

Em razão deste comportamento, na atualidade a palavra cinismo possui uma denotação pejorativa, criada ao longo dos séculos e com grande influência cristã. De acordo com Sylvain Matton (2007, p. 285), vários autores, séculos após a existência de Diógenes, interpretaram seu comportamento como uma "doutrina verdadeiramente inumana", uma vez que, apesar de "todos os sofismas que empregava para afastar os prazeres da sociedade e da civilização, está uma recusa em aceitar a condição humana, que tem as suas raízes num profundo ódio por si mesmo". Assim, tem-se que o entendimento negativo atual para o termo "cínico" surge desta compreensão de que os cínicos na verdade negavam sua própria natureza em razão da admiração pela dos animais e outros seres.

Pelo comportamento de valorização da vida "natural" e por expressar uma simpatia positiva a toda a terra, é possível associar o cínico a um "sentimento de pertencimento a toda a humanidade" (MOLES, 2007, p. 127). Neste sentido se insere o entendimento de que, para os cínicos, a pólis era contra a natureza (MOLES, 2007, p. 123), pois, sentindo-se pertencente a um espaço maior do que a própria cidade, entendiam que ser cidadão apenas desta não correspondia ao comportamento natural. Ou seja, se os animais, modelos de vida na terra, pertenceriam ao lugar onde estivessem, por que o ser humano deveria se vincular a um único local? Assim, o

1 "Diógenes, o primeiro dos filósofos cínicos, nasceu há cerca de dois mil e quatrocentos anos atrás na Grécia, numa cidade chamada Sínope. [...] era filho de um banqueiro de nome Hicésias e se viu, conjuntamente com seu pai, envolvido num escândalo financeiro. Seu pai era o administrador do banco público de Sínope, e havia sido encarregado da tarefa de retirar moeda falsa de circulação. Ao invés disso, Hicésias retirou a moeda verdadeira como sendo falsa, sendo descoberto e desaparecendo de cena. Após isso, Diógenes foi banido de Sínope e para aí jamais voltou, tornando-se, desde então, um filósofo andarilho" (DINUCCI, 2010).

2 Por este motivo, entendia-se que os cínicos se comportavam como animais, sendo que o próprio termo "cínico" se origina da palavra "cães", em grego. Entretanto, por possuir uma atitude positiva quanto ao mundo animal, diferente de grande parte dos filósofos gregos, e entender que eles são modelos de verdadeira vida, em consonância com a natureza, esta alcunha de cães era vista de bom grado por seus "titulares" (MOLES, 2007, p. 128). 
cínico considerava-se um cidadão, entretanto, não unicamente de sua pólis: era um cidadão do cosmos (MOLES, 2007, p. 123).

Tem-se que a visão cosmopolita cínica, assim, acreditava que o homem deveria seguir os seus extintos mais primitivos, não mantendo apego a bens materiais, como propriedades, vestes ou até mesmo comportamentos socialmente aceitos. De fato, o homem era um ser do cosmos, ou seja, não era pertencente a nenhum lugar, ao mesmo tempo em que pertencia a todos. Sendo assim, aos cínicos nenhuma cultura era sobreposta ou superior à outra, sendo que qualquer um poderia adaptar-se ao local onde escolhesse viver.

Os cínicos, no entanto, tinham mais facilidades para adaptar-se e sobreviver devido à existência das cidades. Com o princípio de "usar o que estiver presente", os eles acabavam utilizando-se das beneficies da pólis, seja a segurança proporcionada ou até os alimentos, esmolas e outros bens essencialmente necessários para sua sobrevivência. Por este motivo, é possível falar-se de um "relativismo moral", comparado ao "comportamento hipócrita dos marxistas ocidentais" (MOLES, 2007, p. 124).

No entanto, este "aproveitamento" da pólis não compromete a hostilidade cínica às cidades, uma vez que os cínicos se entendiam necessários a ela. Isto porque, como se apresentava como uma "filosofia missionária", devido ao "seu comportamento caracteristicamente exibicionista, o cínico oferece aos outros seres humanos um modelo para imitar ou uma demonstração da falsidade dos valores deles" (MOLES, 2007, p. 130). Neste sentido, assim como os cães do mundo animal, os "cães" do mundo humano também intentavam mostrar um modelo a ser seguido pelo restante do mundo, sempre pregando o desprendimento, em vários âmbitos.

O cosmopolitismo cínico durante muito tempo dividiu a opinião acadêmica, sendo que atualmente, e já há algum tempo, entende-se que o cosmopolitismo de Diógenes e os primeiros cínicos era puramente negativo (MOLES, 2007, p.123). Esta compreensão origina-se principalmente da "negação da pólis"; entretanto, este motivo, para John Moles (2007, p. 125), não o torna negativo, existindo outros elementos que provam a implicação positiva da filosofia cosmopolita cínica ${ }^{3}$.

É importante apontar a compreensão cínica de "amor pela humanidade" ou benevolência, uma vez que em diversos momentos se encontram comportamentos mais humanos, altruístas, principalmente pelo caráter de outro cínico conhecido,

3 Entre os cinco pontos apresentados por Moles, ressaltam-se os dois primeiros, pelos quais se comprova a ideia de pertencimento amplo, principalmente no relativo ao cosmos, uma vez que se busca ampliar a extensão do pertencimento. Assim, a ideia de cosmos é positiva, visto que não se nega a existência de vínculos, apenas o amplia. Da mesma forma ocorreria se, ao ser questionado sobre sua nacionalidade, um alemão respondesse que era cidadão europeu. Não se trata de excluir um pertencimento, mas torna-lo "maior" (MOLES, 2007, p. 25). Isto se relaciona diretamente com o segundo ponto, uma vez que, a pátria é rejeitada "em favor de um ideal internacionalista ou cosmopolita" (MOLES, 2007, p. 125). Assim, o que se busca é a consolidação de uma cidadania ampliada, sem restrições nacionalistas. 
Crates, identificado por seu cinismo mais moderado do que o de Diógenes (MOLES, 2007, p. 131). Por meio de inúmeros ditos e comportamentos, como, por exemplo, o fato de mencionarem costumes estrangeiros, a compreensão de que todos os seres humanos são dotados de razão e a visão dos seres humanos como uma unidade, se observam elementos que contribuem para o entendimento de que os cínicos acreditavam na possibilidade deu uma "humanidade comum" (MOLES, 2007, p. 133).

De todo o exposto, observa-se uma grande ligação da filosofia cínica com a natureza e o natural, com o estado primitivo das coisas e das pessoas e com um desapego de tudo que não é fundamental para a sobrevivência humana. Ao mesmo tempo, os cínicos apresentam sentimentos conflituosos, pois defendem uma cidadania do cosmos ao mesmo tempo em que desprezam a sociedade humana, intentam ser missionários andarilhos e se preocupam com o resto dos seres humanos ao mesmo tempo em que os desconsideram e, por fim, acreditam em uma sociedade comum humana, excluindo e incluindo a pólis no conceito de cidadão.

De certa forma, alguns destes preceitos cínicos serão reforçados ou reconstruídos com o passar dos séculos (e milênios). Por este motivo, mesmo após um grande lapso temporal separando as filosofias, para fins de divisão do presente trabalho, Immanuel Kant também será considerado um autor "antigo", não por estar próximo do contexto do cosmopolitismo cínico, mas por estar mais distante das doutrinas contemporâneas e modernas. Assim, após o cosmopolitismo cínico, é de fundamental importância apresentar a teoria de Kant, trazida em sua obra "A Paz Perpétua", escrita ainda em 1795, mas com relevantes compreensões que podem ser aplicadas mesmo hoje.

O primeiro ponto a ser levantado acerca da teoria de Kant versa sobre sua possível contradição quanto ao Estado Natural, tão veementemente defendido pelos cínicos gregos. Ao invés de entender o "primitivo" como um fator positivo e exemplar para a sociedade, Kant entende que o estado de natureza entre os homens não é de paz, mas de guerra, e, ainda que não existam efetivos conflitos, a ameaça permanente de hostilidades mantém este teor em um mundo com ausência de controle (NOUR, 2003, p. 11). Nesse sentido, a manutenção ou o incentivo para que o homem viva "de acordo com a natureza" não é bem visto por Kant, uma vez que é a própria índole do homem buscar a guerra.

É necessário ressaltar, no entanto, que existe uma diferença na perspectiva das filosofias cínicas e na do ilustre pensador alemão. Além do facilmente perceptível diferente contexto em que se inserem, se observa que os cínicos utilizam de uma linguagem voltada ao ser humano e à coletividade em termos mais abstratos, ou seja, para a realidade cínica não existe a formação de grandes Estados ou a noção na grande diversidade cultural existente. Normalmente sua teoria se liga com a existência das pólis, que certamente eram grupos menores e consistiam os Estados conhecidos, ao contrário de Kant, que, por viver no século XIX, já possuía a compreensão da imensidão do mundo, de povos e de culturas, uma vez que todos os continentes já 
haviam sido "descobertos".

Assim, Kant entende que a paz entre estados deve ser fundada por "estruturas jurídicas institucionais", no sentido da formação de um estado civil por meio do direito público (NOUR, 2003, p. 11). Com esta estrutura, o ser humano pode escapar do estado de natureza, no qual existe a ausência de direito, e ingressar em um estado no qual é legalmente definido o que é de cada um (NOUR, 2003, p. 11).

É necessário que exista uma estrutura interna nos Estados, com leis destinadas ao povo de determinado local. Esta organização interna é essencial não somente para a comunidade em questão, que poderá ter sua própria constituição e regramento, mas também para as relações internacionais que se dão entre Estados. Nesse sentido, Kant defende que há "uma relação intrínseca entre a estrutura jurídico-política de um Estado e seu comportamento em relação a outros Estados, conferindo a esta exigência de ordem interna uma consequência no âmbito externo" (NOUR, 2003, p. 14).

Em sua obra, Kant aponta como primeira exigência para a paz a condição de Estados Republicanos, em que o povo determine suas leis por si próprio, o que se identifica como "a concepção contemporânea de democracia" (NOUR, 2003, p. 24). Nesse ponto, a organização interna de um Estado pressupõe que exista um acordo entre seus integrantes e, de forma mais intensa atualmente, uma efetiva participação dos cidadãos nas decisões governamentais e estatais. Por isto, hoje, a simples constituição do estado, com seus elementos básicos, apesar de constituí-lo sujeito de direito internacional, sempre será questionada quando não existir o respeito a direitos básicos do ser humano e a possibilidade de que estes tenham ingerência nos rumos de seu país, o normalmente se relaciona o grau democrático existente.

Kant entende que uma "constituição republicana — ou democrática — na ordem interna pode ter como consequência a paz no âmbito externo por ser determinada pela vontade daqueles que assumem o ônus da guerra e que, por isso, provavelmente, não irão querê-la" (NOUR, 2003, p. 24). Nesse sentido, se o povo, que é em geral o mais prejudicado por uma guerra, em razão das privações e mortes de civis que vão à luta, Kant entendia que este pensaria e evitaria ao máximo iniciar um conflito. Assim, se o poder está na mão daqueles que irão sofrer todos os malefícios de uma guerra, provavelmente haveria menos conflitos, uma vez que nem sempre os governantes que os iniciam consideram todas as dificuldades que serão enfrentadas pela nação.

Desde o princípio, Kant deixa claro sua posição quanto a total impossibilidade da constituição de um estado único e universal, posto que "não apenas impossível do ponto de vista político como inaceitável do ponto de vista moral: a diversidade das culturas, que é moralmente desejável, deve ser preservada" (NOUR, 2003, p. 20). Justifica sua posição por entender que nunca haverá uma paz verdadeira emum Estado mundial, sendo necessária uma aliança dos povos, e não um Estado de povos (KANT, 2010, p. 31), além do fato de considerar impossível que todas as culturas existentes possam ser unificadas, o que também não seria uma boa opção. Se existe 
uma multiplicidade de povos e crenças, isso se deve a fatores históricos, geográficos e sociais, que não podem ser simplesmente ignorados.

Kant também denomina esta aliança dos povos de associação de alguns Estados, na qual haveria um congresso permanente de Estados, possibilitada a entrada de qualquer Estado vizinho (NOUR, 2003, p. 18-19). Este congresso não seria permanente, podendo ser dissolvido a qualquer momento, e teria como escopo principal "a ideia de instituir um direito público dos povos que lhes permita solucionar suas controvérsias de maneira civil, como por meio de um processo, e não de maneira bárbara (à maneira dos selvagens), a saber, por meio da guerra" (NOUR, 2003, p. 19).

Especificamente sobre cosmopolitismo, é Kant quem insere o tema dentro do direito. Isto porque, antes do filósofo alemão, o direito possuía duas dimensões, o direito estatal, interno de cada Estado, e o direito das gentes, que significa o direito das relações dos Estados entre si e dos indivíduos de um Estado com os de outros (NOUR, 2003, p. 21). Kant é quem acrescenta a terceira dimensão, o direito cosmopolita, que seria o direito dos cidadãos do mundo, ou seja, não apenas vistos den- tro de seu próprio Estado, mas em um contexto da sociedade cosmopolita (NOUR, 2003, p. 21).

O direito cosmopolita é apresentado por Kant, no artigo terceiro de sua paz perpétua, como uma condição para a paz, uma vez que, por meio deste sentimento de pertencimento cosmopolita, os habitantes da terra constituirão um sistema em que "o ataque a um direito em um lugar da Terra é sentido em todos" (NOUR, 2003, p. 21). A relação que o filósofo faz entre os dois direitos postos (o estatal e o das gentes) e o direito cosmopolita versa sobre o fato de que "um único Estado corresponde à categoria da unidade; vários Estados, no direito das gentes, à da pluralidade; todos os seres humanos e os Estados, no direito cosmopolita, à da totalidade sistemática, que une os dois estados anteriores" (NOUR, 2003, p. 21). Assim, estes três níveis não implicam na superação um do outro, mas na necessidade dos três e de sua coexistência (NOUR, 2003, p. 12).

Neste sentido, se comparado ao cosmopolitismo cínico, tem-se a mesma ideia de não exclusão do nacional ou local, mas de sua inclusão em algo maior, mais amplo, em que todos estejam abarcados. É o cosmos, onde todos os níveis espaciais estão inseridos e pertencer ao maior não exclui o menor. De certa forma, Kant deixa mais explicita sua opção pela conservação da cultura local e nacional, uma vez que entende não existir possibilidades de uma única humanidade (um único Estado). No entanto isto, não o impede de construir outras alternativas para um cosmopolitismo, que, no entanto, ressalta que deverá "se limitar às condições de uma hospitalidade universal" (KANT, 2010, p. 37).

Assim, o cosmopolitismo, no entendimento de Kant, deverá possui este caráter restritivo do direito de hospitalidade, não podendo ser mais do que isso. $\mathrm{Ou}$ seja, não é possível que outros povos aproveitem-se de uma hospitalidade, que con- 
siste no direito do cidadão de visitar todos os lugares da terra, relacionando-se com o outro, para estender sobre este novo território o seu império, exercendo um "direito de estabelecimento" (KANT, 2010, p. 38). Isto porque, existindo uma compreensão cosmopolita de que, em princípio todos possuem direito sobre a terra, ninguém possui mais direito do que o outro. Então, se um povo já está estabelecido em determinado local, ao outro é possível que ocorra um contato e uma visitação, mas sem o interesse de se apropriar deste espaço (NOUR, 2003, p. 22-23) ${ }^{4}$.

Assim, a ideia de um cosmopolitismo, para Kant, deve ser baseada em relações entre Estados bem estruturados internamente, com democracia e possibilidade de participação popular (a qual fortalece a prevalência da paz) e um cuidado com o limite da hospitalidade universal, pela qual todo o ser humano tem direito de visitar todos os lugares, mas sem tentar apropriar-se deste território para si.

A doutrina kantiana, de acordo com Soraya Nour (2003, p. 34), foi retomada na década de 1990 como diretriz para uma politica cosmopolita dos direitos humanos. Entretanto, o que se observou foi uma degeneração da teoria, uma vez que alguns países podem combater os seus inimigos políticos em nome da humanidade, ou seja, tomam para si o conceito universal e reivindica para si próprio a paz, a justiça e o progresso, mas negando-as ao inimigo (NOUR, 2003, p. 34). Assim, o que ocorre é a inversão da ideia cosmopolita para uma usurpação em benefício próprio, sendo que a "política dos direitos humanos serviria para proceder a uma apreciação moral negativa de um oponente, frustrando a limitação juridicamente institucionalizada de um confronto político ou de um combate militar" (NOUR, 2003, p. 34).

De todo o exposto, tem-se que o cosmopolitismo dos antigos, neste caso o cosmopolitismo cínico e o cosmopolitismo de Immanuel Kant, apresentam-se com pontos em comum e pontos de conflito. Entre eles, cita-se a ideia comum de que ser um cidadão cosmopolita não exclui a possibilidade de manutenção de vínculo com o local ou o nacional, ocorrendo apenas uma ampliação no âmbito do exercício da cidadania. Enquanto os cínicos pregavam ser cidadãos do cosmos ou de "qualquer lugar", Kant defendia o direito igualitário de todos de conhecer e entrar em contrato com outras culturas e povos. No entanto, existem indicativos de que os gregos acreditavam na possibilidade de uma humanidade única, o que constituiria um único estado mundial, valor que Kant desde o princípio nega e desacredita, até porque entende que a diversidade de culturas deve ser valorizada.

No próximo item serão tratados os aportes teóricos contemporâneos, de teóricos que coexistiram/coexistem, motivo pelo qual se poderá analisar (in)congruências de suas doutrinas.

4 Neste ponto existe uma crítica expressa ao comportamento "conquistador" do povo europeu perante os povos de outros continentes, como é o caso da América, África e Ásia. Para Kant, as ações europeias em relação aos nativos reduzem o outro à nulidade, tornando a relação entre pessoas impossível. Por este motivo todas as "descobertas" europeias eram tidas como lugares que não pertenciam a ninguém: os povos que ali estavam eram considerados "nada" (NOUR, 2003, p. 23). 


\subsection{AO COSMOPOLITISMO NA CONTEMPORANEIDADE}

O cosmopolitismo, entendido principalmente pela noção de um pertencimento amplo, sem restrições locais ou globais, pelo contrário, englobando ambos, pode ser encontrado em inúmeros estudos teóricos da contemporaneidade, ainda que nem sempre este termo exato seja utilizado. Nesse sentido, serão apresentadas as doutrinas de alguns pensadores sobre o tema e as novas relações estabelecidas internacionalmente entre Estados.

David Held, professor inglês que estuda teoria política (HELD, 1991), inicia explicando que a autonomia - possibilidade de que todos vivam em liberdade -é uma condição para a realização da democracia e orientação de sua institucionalização (HELD, 1997, p. 265). Neste sentido, pode-se entender como necessária a liberdade de cada Estado para definir, internamente, o que lhe interessa de acordo com as necessidades de seu povo. No entanto, quando se trata do âmbito internacional, esta autonomia deve ser relativizada.

O princípio da autonomia, bem como a soberania de cada Estado-nação, é mitigado quando se trata da relação entre Estados, uma vez que ocorre um desprendimento das fronteiras e territórios fixos (HELD, 1997, p. 269). Significa dizer que, no nível da globalização em que o mundo se encontra, é impossível que um Estado possa agir independentemente, sem considerar que outros países, vizinhos ou não, também possuem seus interesses próprios, e que deve haver uma cooperação para que ambos alcancem o que precisam.

De fato, Held expõe que poucas vezes, ou nunca, as comunidades políticas se encontraram separadas como totalidades geográficas isoladas e autossuficientes. Explana que é melhor vê-las como redes de interação superpostas, que se cristalizam ao redor de diferentes esferas e formas de poder e que originam pautas de atividades que não cabem dentro dos limites territoriais do Estado-nação (HELD, 1997, p. 268269).

Por este motivo, "o alcance espacial do Estado-nação moderno não fixou fronteiras impermeáveis contra outras redes, cujo âmbito e dimensão podem ser locais, internacionais ou globais" (HELD, 1997, p. 269), o que acarreta em influências externas heterogêneas dentro de seu território. Devido a este conhecido "intercâmbio", em que o Estado nunca está sozinho na construção de identidades e rumos a ser tomados, não é novidade o fato de que também não tem mais o poder absoluto de tomar decisões, até mesmo algumas que lhe competiriam exclusivamente (veja-se hoje, por exemplo, a necessidade de "aprovação" pelo Conselho nas Nações Unidas para o início de um ataque a outro país).

O fato de não ser possível que um país viva isolado ou tome decisões absolutamente independente de outros não é surpreendente e não determina que a autonomia seja inexistente. No entanto, sendo a autonomia elemento essencial para a manutenção da democracia em um Estado, Held cita inicialmente a guerra como 
um dos fatores que a ameaçam, com base na já analisada teoria de Kant. Isto significa que, quando os cidadãos de um Estado se sentem ameaçados por outro, não é possível que reine a autonomia, o que impossibilita a democracia bem como uma relação equilibrada internacional (HELD, 1997, p. 270).

Torna-se necessário que exista um "direito público democrático" também em âmbito internacional, para que se regulem as relações entre as redes de interação que atravessam as fronteiras territoriais, o que Held denomina de "direito democrático cosmopolita" (HELD, 1997, p. 271). Este "direito público cosmopolita" é apresentado como um direito que deve ser concebido dentro e fora das fronteiras nacionais, sendo um diferente domínio do direito do Estado e das leis que vinculam um Estado ao outro (direito internacional) (HELD, 1997, p. 271-272). Não pode se tornar um direito utópico, mas deve ser um complemento ao direito já existente, com fins de assegurar a democracia em âmbito mais amplo do que o direito público interno.

Quando Held analisa a ideia de hospitalidade universal de Kant como limite ao direito cosmopolita, acrescenta que não é possível de ser realizada quando, por diversos motivos, a qualidade de vida das pessoas é determinada sem a sua participação, sem que sua voz seja ouvida (HELD, 1997, p. 273). Nesse sentido, sustenta que esta democracia cosmopolita que propõe "requer o consentimento ativo dos povos e nações: a participação inicial só pode ser voluntária. Seria uma contradição com a própria ideia da democracia que uma ordem democrática cosmopolita fosse criada por vias não voluntárias, ou seja, coercitivas" (HELD, 1997, p. 276), motivo pelo qual é extremamente necessário que exista o consenso. Somente assim as partes poderiam estar efetivamente envolvidas com este direito democrático cosmopolita e este poderia ser respeitado.

A princípio todos os povos do planeta poderiam participar deste marco, desde que respeitados e considerados seus recursos políticos e culturais. Held entende que em primeiro lugar os países e Estados com governos democráticos deveriam promulgar e defender esta ideia, que seria fortalecida com o tempo, uma vez que estes grupos democráticos poderiam aprender e construir formas democráticas para aplicação também em âmbito internacional, nas relações entre diversos países (HELD, 1997, p. 277). Com isto, ainda, é possível que se crie um "marco institucional" que regule democraticamente os Estados e as sociedades, o que significa um fortalecimento na democracia internacional. De acordo com Held (1997, p. 277), "cada passo avançado na realização da autonomia democrática dentro de um Estadonação ou uma região não será mais do que um marco no caminho da fundação da democracia cosmopolita com alcance global".

Ainda sobre um sistema cosmopolita, Held aponta que ele proporcionaria o desfrute de múltiplas cidadanias pelas pessoas, que poderiam "pertencer" a diversas comunidades (HELD, 1997, p. 278), sem que fosse necessário um desmantelamento dos âmbitos locais e nacionais. Isto porque "a política cosmopolita refletiria e abar- 
caria, em forma e substância, os diversos sistemas de poder e autoridade que operam dentro e através das fronteiras e que, se não forem controlados, constituiriam a ameaça de uma ordem altamente fragmentada, neomedieval" (HELD, 1997, p. 278). Assim, não se trata de extinguir o direito interno nacional, mas estendê-lo para além de suas fronteiras (HELD, 1997, p. 279).

Da teoria apresentada por David Held, tem-se novamente a ideia de pertencimento mais amplo com o foco em possibilitar que a democracia prevaleça nas próximas décadas e séculos. Trata-se de um entendimento global para que esta democracia, ao existir internacionalmente, fortaleça as que existem internamente, além de também propiciar que novas surjam onde a tirania ainda prospera. Como afirma Held (1997, p. 280), "o modelo cosmopolita está baseado no reconhecimento de que a democracia dentro de uma comunidade particular e as relações democráticas entre as comunidades estão concatenadas e são absolutamente inseparáveis". Ou seja, o cosmopolitismo fortalece o global e o local, sendo que um é necessário para a existência do outro.

É neste sentido também que Ulrich Beck, sociólogo que estuda as modificações da sociedade globalizada, entende as polaridades entre o global e o local são princípios interdependentes que se sobrepõem mutuamente. Assim, Beck aponta que os temas globais se tornam cotidianos para o ser humano, por meio de um processo não linear e dialético, denominado por ele como "cosmopolitização" (BECK, 2005, p. 103-104).

Apresenta uma diferenciação entre cosmopolitismo, que aponta estar em um plano filosófico, e a cosmopolitização, que seria o "cosmopolitismo forçado" (BECK, 2005, p. 135). De fato, compreende que esta abertura sociológica, com uma visão globalizada ao invés de apenas nacionalista, já é obrigatória aos Estados, uma vez que, nos mesmos moldes que prega Held, "os perigos globais geram a possibilidade de ações globais, pois o século em que o mundo se colocou em perigo será o século de um único mundo" (BECK, 2005, p. 105) e a "ideia de democracia nacional deverá ampliar-se e reformular-se na ideia de democracia cosmopolita" (BECK, 2005, p. 177). Assim, já não é possível que os Estados se isolem, uma vez que também existem problemas e temas em comum a todos.

Neste sentido, Beck defende a necessidade da substituição do nacionalismo metodológico, que se fecha no próprio Estado, para um cosmopolitismo metodológico, que seria multiperspectivo e detentor de "[...] diferentes lentes que superam e diluem fronteiras dos atores sociais e políticos" (BECK, 2005, p. 117). Aponta que "não existe outro caminho que não seja a o projeto de um marco conceitual alternativo e a produção de novos dados empíricos" (BECK, 2005, p. 106). Ainda, Beck (2005, p. 108) repisa a ideia de "abertura de fronteiras", no sentido de que "com a cosmopolitização, as relações nacionais-nacionais cedem lugar para as relações translocal, local-global, transnacional, nacional-global e global-global (cosmopolitização espacial)", ou seja, já não é possível que se exclua o plano internacional e local 
dos polos agentes de relações.

Ulrich Beck entende que o cosmopolitismo pode ser visto como real ou percebido 5 , que, visto de outro modo, poderia ser intitulado de cosmopolitismo (lado benéfico) e globalismo (quando visto apenas de forma superficial ou forçada, oriundo "de cima para baixo"). Beck não realiza uma diferenciação teórica entre os termos, utilizando, inclusive, globalização e cosmopolitização como sinônimos (ao contrário de outros doutrinadores), mas é perceptível que entende existirem estes dois pólos, diferenciados. Assim, explica que a cosmopolitização percebida (ou banal) apenas reimpõe "[...] os valores do estado nacional e os legitimando por meio de uma visão cosmopolita" (BECK, 2005, p. 105), sendo um "retrocesso da cosmopolitização" (BECK, 2005, p. 105)'.

Beck faz a ressalva, entretanto, de que, apesar deste movimento cosmopolita, poucas são as instituições e projetos que pretendem levá-lo a uma efetivação no futuro, sendo que grande parte das iniciativas ainda possuem escopo nacional (BECK, 2005, P. 112). Ocorre que "[...] os modernistas do velho uso acreditam que só um projeto nacional e onicompreensivo possibilita a integração da sociedade moderna" (BECK, 2005, p. 109), embora Beck aponte que este nacionalismos metodológico focam nas "[...] implicações futuras de um passado nacionalmente compartilhado" (BECK, 2005, p. 111). Já o cosmopolitismo metodológico "[...] trata das implicações presentes de um futuro globalmente compartilhado" (BECK, 2005, p. 111).

Por fim, o último conceito trazido por Beck, importante e necessário de se apresentar, é o de interdependência ou interconnectedness, em inglês. Este termo diz respeito à sobreposição e interdependência crescente nos espaços nacionais, que rompe com o nacionalismo metodológico e torna cada vez mais necessário o trabalho em conjunto dos Estados (BECK, 2005, p. 113). Como exemplos de questões internacionais que ligam estes países, podem-se citar o meio ambiente, a imigração, o terrorismo, entre outros, sendo essencial destacar que também os países ricos se inserem nesta interdependência, uma vez que também são afetados por estes proble-

5 O sociólogo apresenta, ainda, a divisão entre cosmopolitização real, tida como este processo de conhecimento do outro, e cosmopolitização política, que por sua vez "se interessa por criar novas formas políticas que sejam capazes de resolver os problemas da cosmopolitização" (BECK, 2005, p. 106). Seriam, por exemplo, o entendimento de Held de desenvolvimento do direito democrático cosmopolita, pelo qual os Estados aprenderiam a lidar com este novo "conceito" ao utilizá-lo.

6 Como exemplos desta cosmopolitização superficial, pode-se citar a "americanização" e a "mcdonaldização" (BECK, 2005, p. 122), em que apenas aparentemente ocorre uma inter-relação com outras culturas. De fato, a cultura americana se insere em muitos países, entretanto, isto não consiste no cosmopolitismo real, pois este intenta romper "[...] com o intento de consciência nacional insular abrindo-se ao mundo dos outros, respeitando-os, interiorizando a visão dos outros" (BECK, 2005, p. 112), o que não consiste apenas em adotar um estilo ou alimentação estrangeira. 
mas. É visível que, mais uma vez, está presente a comunicabilidade entre fronteiras e a necessidade de formação de diretrizes únicas (ou cosmopolitas) que englobem interesses e necessidades de todos os Estados e com o intuito de proteção de direitos universais.

Para Kwame Anthony Appiah (2007a, p. 18-19), a ideia de cosmopolitismo pressupõe dois aspectos. O primeiro trata da noção de que existem obrigações que se estendem além daquelas que se relacionam a pessoas com graus de parentesco, ou de cidadania. O segundo, por sua vez, versa sobre a necessidade de se valorizar a vida humana, bem como as particularidades que ela possui, de acordo com suas crenças e entendimentos. Neste sentido, um cosmopolita sempre compreende que poderá aprender com as diferenças, e, existindo tanta diversidade, haverá muito a ser explorado.

Expressamente se declarando um cosmopolita, defensor do cosmopolitismo, Appiah defende o direito que cada pessoa tem de "fazer as coisas a sua maneira" (APPIAH, 2007a, p. 18-19). Afinal, é natural de um cosmopolita pensar que "[...] a variedade humana é importante porque as pessoas têm direito a acessar as opções que necessitem para configurar suas vidas em companhia de outras pessoas "7" (APPIAH, 2007a, p. 144-145). Deste modo, ressalta que cada povo se adapta da forma que achar mais conveniente até mesmo a produtos globalizados, como, por exemplo, a Coca-cola, que, enquanto no ocidente é um refrigerante comum, em alguns países é servido apenas em velórios (APPIAH, 2007b, p. 156).

Ressalta que o cosmopolitismo sustentável equilibra o respeito pela diferença com o respeito pelos seres humanos atuais (APPIAH, 2007a, p. 156), mas que, longe de ser a solução para todos os problemas, configura uma aventura e um ideal (APPIAH, 2007a, p. 24), sendo um desafio a toda humanidade que deverá aprender a manter as interpenetrações de povos e modelos de vida de forma que ainda seja possível se construir um marco de proteção e regulação universal.

Sobre esta interpenetração de culturas e sociedades, Appiah indica que é um fenômeno muito antigo e natural para todos, ainda que tenham produzido muita violência junto aos intercâmbios produtivos e amistosos (APPIAH, 2007b, p. 312). Por este motivo, entende que não é possível ser um cosmopolita se busca mudar o mundo sem entendê-lo (APPIAH, 2007b, p. 320), uma vez que o cosmopolitismo impõe esta abertura ao restante do mundo (e suas culturas e modos de vida) e o cosmopolita entende que todo esse mundo é sua pátria, aproximando-se de um conceito de "aldeia global" (APPIAH, 2007b, p. 313).

Como princípio, Appiah entende que um cosmopolita se propõe não a se prender às identidades como vínculo, mas as próprias diferenças como uma forma de união (APPIAH, 2007b, p. 182). Não é possível que persista um entendimento

7 "Los cosmopolitas pensamos que la variedad humana es importante porque las personas tienen el derecho a acceder a las opciones que necesiten para configurar sus vidas en compañía de otros" (APPIAH, 2007, p. 144-145). 
focado na própria cultura, considerando-a melhor do que as outras, posto que uma imagem positivista e que sobrestima alguns aspectos obstaculiza a compreensão intercultural e configura-se em um grande adversário ao projeto cosmopolita (APPIAH, 2007a, p. 47). Disto resulta a necessidade de abertura ao mundo e às suas culturas, compreendendo que estas também podem modificar-se, ao seu modo e em seu tempo, sem necessariamente deixar de existirem (APPIAH, 2007a, p. 148) ${ }^{8}$.

No entanto, apesar de não acreditar em um único governo mundial, Appiah entende que os cosmopolitas devem respaldar o direito dos demais de viver em estados democráticos, com possibilidades de relações dentro e fora de suas fronteiras. Isto porque, ao lutar pelos direitos dentro dos Estados nacionais, um cosmopolita está também lutando pelos seus próprios (APPIAH, 2007b, p. 353).

Para o alemão Otfried Hoffe, é cidadão cosmopolita “[...] aquele que não se atém a fronteiras, que se desloca por todo o mundo, porém que se sente - mais ou menos - em casa em todas as partes por onde anda" (HOFFE, 2005, p. 394). Este conceito vai ao encontro de grande parte do entendimento já apresentado desde os cínicos, sendo que a diferenciação trazida por Hoffe, deste modo, consiste em uma "graduação" do cosmopolitismo, no sentido de que entende existir "níveis" de cosmopolitas.

Desta forma, Hoffe entende que existem os cosmopolitas de primeiro, segundo e terceiro grau. O primeiro seria um "[...] viajante mundial, que, mesmo no estrangeiro, não abre mão de seus vínculos locais e nacionais" (HOFFE, 2005, p. 394). Quanto ao segundo, explica ser mais sofisticado, pois alcança uma "[...] abertura para o mundo que o faça perceber o estrangeiro, reconhecendo-o com igualdade de valor" (HOFFE, 2005, P. 394). Por fim, o terceiro grau de cosmopolita consiste naquele que leva sua própria cultura para outro país "[...] mas se deixa marcar pela nova cultura e não abdica das novas características após o retorno a seu torrão natal" (HOFFE, 2005, p. 394).

Explica, ainda, que no sentido político, o cidadão mundial é "[...] membro de um Estado que abrange todos os seres juridicamente capazes do mundo inteiro" (HOFFE, 2005, p. 394) e que se difere de cidadão do mundo, uma vez que este último seria "complementar". Ou seja, enquanto o cidadão do mundo "[...] corre o risco de se sentir um pouco em casa em qualquer lugar, porém nunca exatamente como se estivesse em casa, o cidadão mundial complementar e federal sente-se em casa tanto em seu país quanto em qualquer parte do mundo inteiro" (HOFFE, 2005, p. 395396).

Hoffe repisa a ideia de um cosmopolitismo em prol de um governo único

8 Appiah distingue o cosmopolitismo do modo como é entendido hoje, como uma abertura ao externo sem excluir o interno, da ideia de um Estado Mundial para governar uma comunidade mundial (APPIAH, 2007b, 314). Desta forma, retoma a ideia de grande parte dos autores já estudados, a exemplo de Kant que, por mais otimista que fosse quanto à paz perpétua entre Estados, jamais considerou possível uma união de governos em um só. 
mundial, diferenciando, por este motivo, os diferentes tipos de cosmopolita, uma vez que somente no último nível este Estado Mundial seria possível (HOFFE, 2005, p. 397-399). No entanto, assim como outros, ressalta as grandes dificuldades para que esta ideia seja concretizada, entre elas sua constituição por sujeitos muito distintos (Estados nacionais e sujeitos naturais ou cidadãos do mundo) e o fato de que não é apenas uma sociedade jurídica, ou seja, não se esgota apenas em uma ordem estatal mundial (HOFFE, 2005, p. 503), entre outras (como a intervenção da economia e a dificuldade de "internacionalização" de alguns temas).

O pensador denomina de "terceira revolução democrática" a formação de um Estado Mundial, sendo a primeira ocorrida na Grécia e a segunda durante a Idade Moderna (HOFFE, 2005, p. 509). Quanto à possibilidade da formação deste governo único, Hoffe demonstra-se cauteloso, uma vez que atualmente os países tendem a distanciar-se e a própria Organização das Nações Unidas não alcança seus objetivos, como a formação de um estado jurídico global, embora ressalte que grandes alianças regionais, como a União Europeia, sejam fascinantes para outros países do mundo que estão em estágios intermediários (HOFFE, 2005, p. 511).

De todos os posicionamentos expostos, é possível destacar, ao menos, um ponto em comum, qual seja, a não exclusão, em um projeto cosmopolita, do local ou do nacional. Pelo contrário, do cosmopolitismo cínico, passando pelo de Kant, Held, Beck, Appiah e Hoffe, o que percebe é o intuito de conexão entre diferentes culturas, que apesar das diferenças e da grande diversidade, possuem um objeto em comum: a humanidade.

Assim, o próximo item pretende inserir o tema da proteção dos direitos humanos no âmbito internacional, por meio de um projeto cosmopolita para a internacionalização do direito, como ferramenta para o fortalecimento de democracias internas dos Estados Nacionais, com especial atenção ao direito humano à informação.

\section{A ATUAÇÃO DO COSMOPOLITISMO NA PROTEÇÃODA DEMOCRA- CIA NOS ESTADOS NACIONAIS: AS PONTES DE TRANSIÇÃO ENTRE JUSTIÇAS NA GARANTIA DO DIREITO À INFORMAÇÃO DO CIDADÃO}

O projeto cosmopolita de inclusão e adição das três esferas espaciais (local, nacional e global) é uma peça-chave para a possibilidade de um "acordo" entre Estados, no qual direitos pertencentes à humanidade como um todo possam ser garantidos. Neste contexto, com base no cosmopolitismo, busca-se um caminho para a integração internacional, principalmente no pertinente à proteção de direitos humanos.

Assim, os próximos títulos irão tratar da possibilidade de influência recíproca na relação global-nacional, pela qual uma esfera fortalece a outra. Na primeira parte, busca-se analisar a teoria do transconstitucionalismo, de Marcelo Neves, que propõe "pontes de transição" entre países para a internacionalização do direito. $\mathrm{Na}$ 
segunda, por meio desta possibilidade de diálogo entre ordens jurídicas, por fim, tratar-se-á da proteção do direito humano à informação como elemento fundamental da democracia nos Estados Nacionais, requisito básico para o ideal cosmopolita tomar forma e, ao mesmo tempo, direito garantido por este.

\subsection{DA CONSTRUÇÃO DE PONTES DE TRANSIÇÃO ENTRE ESTADOS: A TRANSVERSALIDADE ENTRE SISTEMAS DE JUSTIÇA NA GARANTIA DOS DIREITOS HUMANOS.}

O projeto de um cosmopolitismo a ser aplicado perante as relações entre Estados nacionais para a internacionalização de direitos pode ser observado de outras perspectivas, por meio de termos distintos, mas que apresentam ideias semelhantes de proteção de bens comuns e pertencimento ao global.

De acordo com Morais, Saldanha e Vieira (2013, p. 18-21), é importante diferenciar estes quase sinônimos, como é o caso dos termos globalização, internacionalização, transnacionalização e planetarização. Consoante explanam, globalização é o mesmo que mundialização, e refere-se "[...] ao recorte econômico dessas mudanças que são efetivamente multidimensionais [...]", sendo que internacionalização, por si, diz respeito à relação entre nações e a transnacionalização às relações internacionais que transcendem e dispensam o Estado nacional para existirem(MORAIS, SALDANHA e VIEIRA, 2013, p. 19) ${ }^{9}$.

Ademais, referem que globalização e universalização não se confundem, posto que a primeira, em geral, versa mais sobre economia e a segunda implica em compartilhar sentimentos, ou seja, se volta aos direitos humanos (MORAIS, SALDANHA e VIEIRA, 2013, p. 20). No mesmo sentido, Têmis Limberger aponta que "a globalização da economia não significa globalização dos direitos", sendo necessário que caminhos sejam trilhados para que estes se efetivem (LIMBERGER, 2013, p. 274). Por esta razão, um projeto internacional ou cosmopolita, nos moldes apresentados no tópico anterior, se mostram necessários para a concretização de direitos pertencentes a toda a humanidade.

De acordo com Saldanha (2011, p. 349), “[...] impera a necessidade de observação de uma solidariedade transnacional e transtemporal, na consideração do humano como elemento comum, sem jamais desconsiderar a diversidade cultural". Desta forma, o direito já não mantém unicamente seu caráter de normatividade estatal, "tornando-se supraestatal e, até mesmo inter-humano" (SALDANHA, 2001,

9 Em âmbitos mais específicos, outros termos que se relacionam à globalização podem ser citados. Entre eles está a "americanização", que é relativo à influência cultural e ideológica dos Estados Unidos; a "europeização", que se relaciona à influência europeia, principalmente durante os períodos de colonização preconizados pelos europeus; e a "regionalização", que indicam as inter-relações entre Estados pertencentes a determinada região geográfica (MORAIS, SALDANHA e VIEIRA, 2013, p. 20). 
p. 349), uma vez que é necessário que se realizem novos processos de formação de valores para o fim único de alcançar os direitos que são de toda a humanidade.

Para a realização desta referida universalização, em que, no mínimo, os direitos humanos e fundamentais poderão ser objeto de proteção de todos os Estados, entende-se que, como já apontado no primeiro ponto deste trabalho, a formação de um único governo mundial não é a solução, uma vez que muitos seriam os entraves para que fosse constituído. No entanto, outros processos ou movimentos existem, alternativamente, principalmente pelo fato de que a interpenetração de países é muito visível na sociedade atual, sendo que "[...] cada vez mais as deliberações tomadas nas relações internacionais afetam de maneira mais rápida e impactante a vida no interior dos Estados Nacionais" (MORAIS, SALDANHA e VIEIRA, 2013, p. 28).

Deste modo, podem ser citadas teorias, de diversos autores, que versam sobre as influências dos sistemas jurídicos externos sobre os internos ${ }^{10}$. Por entender que o cosmopolitismo pode ligar-se a uma visão sob o aspecto interestatal e interconstitucional, além da possibilidade de aplicação de uma teoria por meio de "pontes de transição" entre Estados, neste momento será apresentada a teoria do transconstitucionalismo, formulada por Marcelo Neves. Objetiva-se, assim, demonstrar ao menos uma das perspectivas existentes para a consagração de intercâmbios entre esferas sociais distintas que possam servir como parâmetros de proteção dos direitos humanos.

O conceito de Constituições transversais trazido pelo autor brasileiro diz respeito ao "entrelaçamento entre o direito e a política" e na "relação entre sistemas funcionais", o que resulta em "[...] externalização e internalização de informações entre esferas sociais que desempenham funções diversas e se reproduzem primariamente com base em códigos binários de comunicação diferentes" (NEVES, 2009, p. 115). Significa dizer, consiste na interpenetração de sistemas distintos, como é o caso de constituições internas dos Estados Nacionais.

Uma constituição transversal de Estado constitucional, desta forma, funciona como "[...] instância da relação recíproca e duradoura de aprendizado e intercambio de experiências com as racionalidades particulares já processadas [...] na política e no direito" (NEVES, 2009, p. 62). Assim, esta constituição possui duas formas de transversalidade: a que diz respeito à Constituição Jurídica, própria de um conjunto de normas, e a que diz respeito à Constituição Política, como processos decisórios sobre decisões coletivas (NEVES, 2009, p. 63).

10 Sob o aspecto interno, tem-se o "direito constitucional comparado", de Bóris MirkineGurtzévitch, a "internacionalização do direito", a "internacionalização do direito constitucional", a "internacionalização do poder constituinte", a "harmonização e uniformização do Direito pela via do direito internacional privado" e a "internacionalização dos juízes nacionais", esta última de Delmas-Marty (MORAIS, SALDANHA e VIEIRA, 2013, p. 29-31). Já no pertinente ao aspecto interestatal e interconstitucional, citam-se a "rede de interconstitucionalidade", de Manuel Castells, o "transconstitucionalismo", de Marcelo Neves e o "constitucionalismo multinível". 
Esta racionalidade interna, que consiste em uma "solução juridicamente consistente", calcada na legalidade, é de essencial importância para que exista também uma justiça constitucional externa (NEVES, 2009, p. 64). Isto porque sem a estrutura básica interna, em que os próprios Estados estejam previamente regrados de acordo com seus interesses (de seu povo), não existe possibilidade de um acordo em âmbito internacional. Não é possível que um país que não esteja funcionando bem internamente possa participar de comunidades (ou de uma comunidade) entre países, uma vez que estas também são muito frágeis e dependem da força autônoma de cada Estado para existirem. Mais uma vez, tem-se uma perspectiva da dependência entre local, nacional e global.

De todas as formas, "a emergência de ordens jurídicas internacionais, transnacionais e supranacionais [...] é um fato incontestável que vem chamando a atenção e tornando-se cada vez mais objeto de interesse de estudos [...]" (NEVES, 2009, p. 83). Ocorre que novos problemas vêm exigindo soluções que as constituições nacionais não conseguem apresentar, sendo necessário o uso destas "novas ordens jurídicas" para que se encontrem os caminhos alternativos, que possam tratar de temas diversos e complexos, como é o exemplo das políticas de segurança, do comércio mundial, do direito ambiental e dos direitos humanos (NEVES, 2009, p. 83).

Estes problemas, denominados de "bens comuns da humanidade" por serem transterritorializados, apesar de configurarem muitas vezes casos comuns, normais do cotidiano, atingem diretamente as ordens jurídicas envolvidas, uma vez que sempre geram certa "competição" entre Cortes de Justiça e Tribunais, que desejam "impor" suas ordens sobre outras jurisdições (NEVES, 2009, p. 128). No entanto, tratando-se de bens comuns, já não é possível que as decisões sejam totalmente independentemente, pois, se os próprios países já possuem uma interdependência, em vários âmbitos, não será no jurídico que poderão isolar-se. Por este motivo, aumentam as discussões acerca da possibilidade da constitucionalização do direito internacional e das teorias "cosmopolitas", por assim dizer, como são as de Kant, Held, Hoffe, entre outras.

Das várias possibilidades, entre a construção de uma "República mundial Federal e subsidiária" (Kant) e uma "política interna mundial, sem um governo mundial” (Habermas) (NEVES, 2009, p. 85-86), destaca-se o não desaparecimento de Estados nacionais ou locais, visto que se busca uma "estatalidade mundial inclusiva" (NEVES, 2009, p. 87), ou seja, ao invés de excluir o local ou o nacional, o insere no contexto global. Neves, no entanto, no que diz respeito à possibilidade de uma constituição mundial, entende que seria um projeto ideal e altamente complexo para ser realizado dentro de uma perspectiva internacional, posto que esta "comunidade mundial" permaneceria sendo constituída por variados países e culturas e não poderia ser considerada um Estado verdadeiro (NEVES, 2009, p. 88).

Ademais, apresenta vários entraves para que uma constituição mundial fosse realizada de comum acordo por todos seus participantes, como, por exemplo, 
o fato de que as grandes potências costumam determinar as políticas de direito internacional (NEVES, 2009, p, 92). Como exemplo, traz as intervenções humanitárias, realizadas por países como os Estados Unidos que se apresentam como legítimos defensores dos direitos humanos no planeta. Mas, no contexto mundial, questiona: "[...] quem é competente para decidir e implementar a proteção de direitos humanos contra Estados ou organizações que os violam sistematicamente?” (NEVES, 2009, p. 94). Na realidade, tem-se que os direitos humanos servem como meros pretextos para resolver questões políticas entre Estados com poderes bélicos e seus "não aliados" (NEVES, 2009, p. 96).

De fato, os direitos humanos buscam a proteção do mínimo necessário para a vida digna do ser humano, garantindo-os, sejam estes direitos de qualquer âmbito (civil, social, econômico, cultural, ambiental, etc). Assim, devem ser " [...] considerados e realizados de forma integrada e indivisível (indivisibilidade), a todos os seres humanos no planeta Terra, indistintamente (universalidade), ou seja, de todos, em todos os lugares" (MORAIS; SALDANHA; VIEIRA, 2013, p. 22).

Ocorre que sendo um bem comum da humanidade, estes direitos necessitam de uma "conversação" entre cortes de justiça, "diálogo" este que consiste em "comunicações transversais perpassando fronteiras entre ordens jurídicas", que podem se dar em diversos níveis: internacional, nacional, regional, etc (NEVES, 2009, p. 117). Desta forma, ocorre uma "fertilização constitucional cruzada", termo utilizado por Neves para apontar as inter-relações entre cortes de justiça que "[...] dispõem-se a um aprendizado construtivo com outras cortes e vinculam-se às decisões destas" (NEVES, 2009, p. 119).

Além disso, é importante ressaltar que algumas dessas interações entre ordens jurídicas distintas se dão independentemente de tratados ou convenções entre Estados, ocorrendo de forma "transnacional". São as denominadas "pontes de transição" entre ordens jurídicas, pois ligam jurisdições distintas sem a necessidade de intervenção dos Estados Nacionais, que permanecem sem poder de ingerência neste quesito. Neves destaca que estas pontes “[...] não são construídas de maneira permanente e estática no âmbito dinâmico do transconstitucionalismo. O processamento dos casos vai exigir uma postura indutiva de construções e reconstruções de estruturas de acoplamento no plano das novas operações do sistema" (NEVES, 2009, p. 129), uma vez que as "pontes" não são códigos ou regramentos fechados e, por isso, são passíveis de modificação de acordo com os entendimentos dos Tribunais atores nos casos concretos.

Assim, o "transconstitucionalismo" de Marcelo Neves, em suas palavras é "[...] um constitucionalismo relativo a (solução de) problemas jurídicos-constitucionais que se apresentam simultaneamente a diversas ordens" (NEVES, 2009, p. 129). Quando se tratam de direitos humanos e fundamentais, são submetidos ao "tratamento jurídico concreto", o que requer que as jurisdições envolvidas estejam comprometidas com estes valores e "[...] levem a sério os problemas básicos do 
constitucionalismo" (NEVES, 2009, p. 129).

Se os Estados não estiverem bem estruturados, com constituições veiculadas em sua perspectiva jurídica e política e em consonância com a democracia e o respeito aos direitos humanos, não será possível que seja realizada a edificação das "pontes de transição", que requerem, no mínimo, postulados em prol da proteção dos direitos da humanidade. Neste sentido, é possível apontar que "[...] a internacionalização pode ocorrer no sentido do fortalecimento da identidade jurídica nacional, ainda que a ressignificando" (MORAIS; SALDANHA; VIEIRA, 2013, p. 48). Assim, não se trata de excluir o nacional, mas de modifica-lo e adaptá-lo à realidade atual, na qual nenhum país existe independentemente de outros. Trata-se de reconhecer o entrelaçamento das diversas ordens jurídicas, o que transforma também o constitucionalismo.

Constitui-se uma "transformação conteudística do Estado", uma vez que suas dificuldades afetam o constitucionalismo, que se transfere do âmbito nacional para o regional e, possivelmente, "projeta um âmbito mundial/cosmopolita", com a utilização de documentos construídos internacionalmente. São exemplos desta reestruturação os tratados internacionais de direitos humanos, bem como as novas possibilidades de práticas jurisdicionais, como é o caso das "pontes de transição" que realizam o diálogo entre ordens jurídicas distintas (MORAIS; SALDANHA; VIEIRA, 2013, p. 46).

É necessário que se pense na possibilidade de um direito pluralista, sujeito a ajustes (como a margem nacional de apreciação) e considerando-se também, além do diálogo de jurisdições, um diálogo intercultural (SALDANHA, 2011, p. 350), em que as diferenças possam fortalecer o relacionamento entre Estados, tornando-o "aberto ao mundo" ou, simplesmente, cosmopolita.

De todo o exposto, tem-se que, ainda que não seja criado um governo mundial único, com vistas a uma internacionalização do direito em que ao menos os direitos humanos mais básicos sejam protegidos, existem alternativas que podem servir para a resolução destes "problemas comuns" da humanidade. Desta forma, ainda que politicamente Estados não consigam entrar em acordos ou construir uma constituição mundial, as diversas ordens jurídicas podem, por meio de pontes de transição, dialogar e encontrar os melhores caminhos para efetivar estes direitos.

Entre os tantos direitos humanos protegidos em âmbito constitucional, que versam normalmente sobre direitos de liberdade, igualdade e fraternidade (ou solidariedade), alguns se destacam na atualidade por também fortalecer os Estados Nacionais internamente. Este fator é de extrema relevância para que se possa construir uma "simetria" entre estes Estados que "negociam", de modo que nenhum seja inferiorizado ou ignorado. E entre os elementos essenciais para este fortalecimento interno, tem-se que a democracia é ponto chave, visto que somente se a nação do Estado possuir poder de voz, este Estado respeitará o ser humano como fim último, e não intermediário. 
Por este motivo, no próximo e último tópico, serão apresentados os direitos humanos no contexto internacional bem como a utilidade e essencialidade do direito humano à informação para a efetivação da democracia no âmbito interno dos Estados Nacionais.

\subsection{AO DIREITO HUMANO À INFORMAÇÃO POR UMA DEMOCRATIZA- ÇÃO MUNDIAL}

O direito à informação ingressou na esfera legislativa como direito humano passível de proteção há algumas décadas, com a Declaração Universal dos Direitos do Homem, de 1948, da ONU ${ }^{11}$, e posteriormente no Pacto Internacional de Direitos Civis e Políticos (MENDEL, 2009), sendo que, ainda atualmente, não são muitos os Estados que têm este direito amplamente difundido e expressamente protegido em suas Constituições. Podem-se citar, além da Constituição Brasileira, que o consagra em seu art. $5^{\circ}$, as constituições Portuguesa, Espanhola e Sueca (CARVALHO, 2003, p. 85), entre outras.

Apesar de hoje ser expressa sua importância, este direito nem sem sem- pre teve o status de direito humano, sendo que somente foi incorporado a este rol após a "evolução" dos direitos humanos, o que se deu conjuntamente com o Estado Moderno e é explicado pela Teoria das Gerações de Direitos. Consoante esta teoria, atualmente os direitos humanos ou fundamentais se dividem em três grupos: os direitos de primeira, os de segunda e os de terceira geração. Em uma breve síntese, esta teoria, criada por Karel Vasak em 1979 (PÉREZ LUÑO, 2012, p. 17), interliga os direitos fundamentais à evolução do Estado Moderno, que se iniciou com o Estado Liberal, passou pelo Social e hoje se encontra no Estado Democrático de Direito.

Neste sentido, de acordo com as necessidades de cada época da história, eram fixados os direitos mais essenciais do ser humano. Assim, na primeira geração tinham-se os direitos relativos à liberdade do indivíduo, na segunda os direitos relativos à igualdade (direitos sociais) e na terceira os novos direitos, que são representados pela palavra solidariedade (STRECK; MORAIS, 2006), uma vez que somente são atingidos quando buscados em conjunto. É o exemplo do direito à paz, ao meio ambiente, à qualidade de vida, ao desenvolvimento dos povos, entre outros (PÉREZ LUÑO, 2012, p. 18), que também podem ser considerados bens comuns da humanidade, nos termos utilizados por Marcelo Neves.

Atualmente entende-se que a sociedade encontra-se na terceira geração dos direitos fundamentais, nos quais também se inserem direitos relativos às novas tecnologias, como, por exemplo, a Internet. Sabe-se que desta ferramenta originam-se

11 O direito à informação está previsto em seu artigo 19, in verbis: Todo o indivíduo tem direito à liberdade de opinião e de expressão, o que implica o direito de não ser inquietado pelas suas opiniões e o de procurar, receber e difundir, sem consideração de fronteiras, informações e ideias por qualquer meio de expressão (ONU, 1948). 
novas possibilidades e também novos riscos aos seres humanos, sendo que "[...] na atual etapa de desenvolvimento tecnológico, junto aos avanços e progressos tecnológicos, tem sido gerados novos fenômenos de agressão aos direitos e liberdades" (PÉREZ LUÑO, 2012, p. 22).

Como exemplo de atuais violações e de novos direitos a serem tutelados, cita-se o direito à intimidade e à privacidade, que tomou novos contornos com a possibilidade de vigilância constante do Estado sobre o cidadão, com o uso de "[...] videocâmeras de segurança [...] ou de controle da atividade no local de trabalho, os programas de televisão interativos e os rastreadores em Internet" (LIMBERGER, 2007, p. 29).

Entretanto, se destas tecnologias derivaram novos riscos, outros tantos direitos fundamentais foram consolidados, bem como novas formas de viver os valores democráticos foram criados. Não seria "[...] lícito omitir [...] as grandes vantagens e possibilidades de atuação que emanam do uso adequado das NT e das TICs" (PÉREZ LUÑO, 2012, p. 42, livre tradução), que permitem "[...] um reforçamento dos valores cívicos e novas formas de exercício dos direitos e podem contribuir para um reforçamento do tecido participativo das sociedades democráticas" (PÉREZLUÑO, 2012, p. 42, livre tradução). Entre estes direitos de terceira geração fortalecedores da democracia, pode-se citar o Direito à Informação.

A informação, atualmente, pode ser considerada a "base da vida e das relações humanas e sociais" (GONÇALVES, 2003, p. 17). Isto porque quem possui o poder de comunica-la, em regra, possui o poder de controle dos cidadãos, que tomarão decisões a partir do que conhecem. Nesse sentido, ao mesmo tempo em que a atual sociedade possui mais condições de acesso à informação, o que permite que se amplie o conhecimento sobre o ser humano, a sociedade e o planeta, é possí- vel que estas modernas condições (especificamente aquelas propiciadas pelas novas tecnologias da comunicação e da informação) sejam "[...] apropriadas por Estados e empresas, e utilizadas em prol de interesses particulares, de forma que o que se transmite à humanidade é, de fato, informação manipulada, que ao invés de esclarecer, confunde" (SALDANHA, 2013, p. 175).

Nesse sentido, no momento em que determinada classe ou grupo social pode determinar a informação que será transmitida, esta se transforma em "consentida", que será não somente filtrada como também poderá ser distorcida para ir ao encontro de interesses de determinados grupos (CARVALHO, 2003, p. 92). Este panorama, no entanto, se modifica diante das atuais possibilidades de comunicação, como é o caso do computador ligado à rede mundial de computadores. Não estando isolados, mas interligados em redes, os computadores permitem que os dados e informações dos internautas, postados na Internet, "[...] saiam de um âmbito restrito e sejam transmitidos globalmente e com uma velocidade ímpar, combinando os fatores de tempo e espaço" (LIMBERGER, 2013, p. 278).

De fato, diante "da globalização das relações, em que a rainha é a 'atua- 
lidade' [...]" (SALDANHA, 2013, p. 183), o que interessa aos cidadãos é a rapidez pela qual a informação deve ir e vir, sendo necessário comunicar e informar, no sentido de expressar-se e informar-se, "a qualquer preço e a um ritmo veloz" (SALDANHA, 2013, p. 183). Neste sentido, Têmis Limberger (2013, p. 279) indica que o direito à informação pressupõe estes dois aspectos: informar e ser informado. E é esta "liberdade" que possibilita que cidadãos possam garantir a democracia em seu Estado, uma vez que somente com a correta informação poderão ocorrer debates sérios que resultem em decisões acertadas para os interesses da nação.

Aimportância do acesso à informação no contexto democrático explica-se quando se considera que a ideia de democracia moderna tem suas origens na Antiguidade Clássica Ateniense e possui uma base local. De acordo com Pierre Lévy (2002, p. 76, grifos do autor), referindo-se a democracia, "[...] se foi inventada em cidades e não em impérios foi porque a comunidade de vizinhança é, de certo modo, o degrau natural a partir do qual compreendemos que determinados assuntos respeitantes ao conjunto da comunidade devem ser regulamentados e decididos conjuntamente".

Sendo a decisão tomada entre todos, o debate entre os cidadãos (na Antiguidade representada apenas pelos homens livres) era peça fundamental para o funcionamento da democracia e, devido ao fator localidade, podia ser bem executado através das ágoras ou praças públicas gregas. A existência destes locais, normalmente situados no centro da pólis, propiciava a realização de uma democracia direta, com igual direito à voz e ao voto para todos os cidadãos.

Embora esta característica organizacional relativa ao processo de votação e eleições seja frequentemente compreendida como fator principal da democracia, os elementos "debate" e "argumentação pública" têm sido abordados com mais frequência na filosofia política contemporânea, consoante aponta Amartya Sen (2011, p. 358). Isto porque a visão de democracia voltada apenas ao concernente às eleições e à votação secreta é a mais formal e antiga delas, sem a perspectiva do governo por meio do debate, e vem sendo superada. O desenvolvimento da sociedade atual, [...] marcada pelo uso intensivo das TICs, com ênfase na internet, [...] não se esgota (e nem deve se esgotar) no processo eleitoral (SANTOS; BERNARDES; ROVER, 2012, p. 19). A opinião pública e o debate, assim, ganham espaço nos governos democráticos, e a informação, neste contexto, é a protagonista para a realização qualitativa daqueles.

Ainda, Stuart Mill, também defensor do governo através do debate, explica que somente através da discussão o ser humano pode chegar mais perto de uma verdade (MILL, 2011, p. 87). Somente através de questionamentos alguns dogmas podem ser revistos e repensados, não havendo consequências negativas sobre essa atitude, uma vez que se a verdade tida como absoluta for discutida e mais uma vez considerada a "melhor" entre as verdades, será mantida; por outro lado, se a conclusão for por outra verdade, a sociedade sairá ganhando, já que terá evoluído (MILL, 2011, p. 58). 
Para Mill (2011, p. 48), ao "amordaçar" uma verdade, o que ocorre é que se pressupõe a infalibilidade humana, tendo em vista que se defende que a ideia deve ser protegida por ser a única dotada de "certeza". Ainda que seja a melhor verdade, ignorar e silenciar outros argumentos torna-se prejudicial, já que ao invés de comprovar-se mais uma vez ser a melhor opção, mantem-se um "dogma morto".

Entretanto, muitas vezes manter verdades "escondidas" ou propriamente ocultá-las pode responder a interesses de uma minoria, que se beneficia desta situação. Isso justifica o fato de que "[...] o direito de informar tornou-se não apenas um dever, mas um poder de informar" (SOUZA, 2005, p. 244). Somente se detentora de informações a população poderá exercer um "controle" sobre as ações e políticas governamentais.

Rogério Gesta Leal (2011, p. 146) explica que os níveis de democracia de uma sociedade são dependentes dos índices de conhecimento e participação social em esferas de debate e decisão política que essa possui, além da difusão da informação no cotidiano, que seria a "única maneira legítima de propiciar ao cidadão se constituir como ator decisivo no espaço público".

Fernando Galindo Ayuda aponta ainda que a participação política não pode efetivamente ser posta em prática sem a satisfação do requisito prévio de que os cidadãos estejam informados ou tenham suficiente conhecimento sobre sua participação (GALINDO AYUDA, 2012, p. 36). Assim, explica o professor espanhol que para a execução de um sistema político democrático é essencial a "[... ] participação consciente e informada dos cidadãos no exercício do poder político, indiretamente mediante a eleição de seus representantes ou diretamente colaborando na tomada de decisões políticas utilizando outros mecanismos" (GALINDO AYUDA, 2012, p. 37, livre tradução).

Disto tem-se que o direito à informação, apesar de amplamente espraiado na atual sociedade informacional, sempre se configurou como necessário para a efetivação da democracia, que pressupõe informação para debate e decisão. O direito de expressão, neste sentido, se insere como "[...] elemento estrutural da democracia, uma vez que torna possível a dissidência e o pluralismo” (SALDANHA, 2013, p. $185)$.

Assim, sendo importante a proteção deste direito humano para a concretização do ideal democrático, que torna os Estados Nacionais fortalecidos e capazes de realizar contatos externos com mais facilidade e credibilidade, é necessário que este direito seja garantido nos regramentos internos de cada nação. No entanto, este cenário se apresenta de mão dupla, pois, ainda que um Estado estruturado internamente seja necessário para a efetivação de um ideal cosmopolita, bem como para a internacionalização do direito por meio de "pontes de transição", é possível que o exterior interfira e influencie o contexto nacional, graças à interpenetração de fronteiras ocasionada pela globalização.

Ainda, é certo que a utilização da globalização apenas em seu sentido es- 
trito de compartilhamento relacionado ao comercio mundial não será suficiente para a existência de um diálogo coerente entre ordens jurídicas. É necessário que seja realizada a mundialização, ou seja, a troca e concretização de valores que objetivem a proteção dos bens comuns da humanidade, entre eles o próprio ser humano e seus direitos fundamentais. Por este motivo, é essencial que se reconheçam nos direitos humanos não apenas conceitos pré-estabelecidos, mas processos dinâmicos (SALDANHA, 2013, p, 180), que possam ser adaptados e aperfeiçoados ao longo da evolução das sociedades.

Desta maneira, o direito à informação, como elemento fundamental para a democracia dentro dos Estados Nacionais se apresenta garantido pela atual ordem internacional, como na citada Declaração dos Direitos Humanos, tida como "momento fulcral para o estabelecimento dos direitos humanos como indicador ético do processo de mundialização" (MORAIS; SALDANHA; VIEIRA, 2013, p. 24), bem como garantidor desta ordem, uma vez que fortalece democracias internas e possibilita uma ordem mundial, ou, ainda, uma conversação entre as ordens existentes.

Portanto, se "[...] a sociedade democrática reivindica o pluralismo informativo, o livre acesso e a circulação de informações" (LIMBERGER, 2013, p. 292), não se trata apenas de garantir a democracia em âmbito nacional. O que se pretende é garantir a democracia nacional, local e global, uma vez que, dentro da perspectiva cosmopolita, estes não se separam, se complementam. E, se efetivamente o fortalecimento de um conseguir fortalecer o outro, por certo, o ideal milenar cínico de ser um "cidadão do cosmos" poderá ser alcançado.

\section{CONCLUSÃO}

A ideia da possibilidade de uma ampliação do pertencimento do ser humano não apenas ao seu Estado ou a sua cultura surgiu há milhares de anos, ainda na Grécia Antiga. De acordo com os cínicos, o ser humano deveria ser um cidadão do cosmos, ou seja, alguém que se sentisse em casa em qualquer ponto do globo terrestre.

Ao longo do tempo, este projeto evoluiu e modificou-se, sendo construído por diversos teóricos. Ainda no século XVIII, Immanuel Kant "relançou" o cosmopolitismo, com novos contornos, bem como no século XX e XXI muitos foram os autores que compuseram e trabalharam neste conceito. Entre eles, citam-se David Held, Ulrich Beck, Kwame Anthony Appiah e Otfried Hoffe, que, apesar de muito distintos, entrelaçam seus entendimentos para a concretização de um ponto em comum: a construção do global por meio do nacional e o fortalecimento recíproco de um pelo outro.

Ocorre que o projeto cosmopolita possibilita, ainda hoje, uma aplicação prática. Seja por meio de diálogos e pontes de transição entre Estados ou pela busca de normas comuns mundiais, atualmente representados pelos acordos e convenções 
tradicionais, a proteção de direitos pertencentes à humanidade como um todo requer uma aspiração e inspiração no cosmopolitismo, visto que somente com respeito ao seu princípio de não sobreposição de culturas e povos sobre outros será possível que esta tutela seja realizada.

Desta forma, quando presente a consciência de que o outro não é o inimigo e que possui diferenças que podem fortalecer e até mesmo unir os povos, torna-se possível que os Estados nacionais reduzam o protecionismo e o egoísmo em benefício apenas da própria cultura e "se abram" para o novo, que consiste em novas ideias, diferentes possibilidades e, até mesmo, um futuro em comum (acordo).

O conceito de "pontes de transição", trazido por Marcelo Neves, neste contexto, é uma excelente alternativa para a resolução de problemas comuns ao ser humano e ao planeta. Entretanto, somente poderá se concretizar diante de uma postura cosmopolita, uma postura em que se aceite que nenhum Estado pode governar sozinho bem como nenhum país no mundo pode isolar-se ou ser totalmente independente de seu vizinho.

Demonstrou-se que, ao mesmo tempo em que a formação de um "consenso mundial" depende de Estados bem estruturados internamente, constituídos e mantidos em democracia, também a esfera nacional pode se fortalecer em razão do internacional, principalmente quando existem direitos protegidos universalmente e que garantem este valor. É o caso do direito humano à informação, que se mostra essencial para a existência de um governo democrático desde a Grécia antiga (assim como o cosmopolitismo) e que hoje está ainda em grande expansão, em razão do contexto de uma sociedade informacional.

Sendo um fato elementar para a democracia interna, que é também elementar para um contexto mundial, tem-se que este último também contribui para sua proteção. Isto porque o global, nos aparatos que já possui, prevê a proteção do direito à informação e de outros direitos humanos, o que resulta em um círculo sem fim: o global auxilia a proteção de elementos estruturantes do nacional que por sua vez integra o global e o fortalece. Trata-se do objetivo cosmopolita, pelo qual um espaço influencia e depende do outro, sem que para isso algum deles seja excluído.

De todo o exposto, tem-se que o ideal cosmopolita, apesar de possuir suas raízes há milênios de anos atrás, continua em voga como uma necessidade para o fortalecimento de Estados e de relações entre eles. Não apenas isso, versa sobre uma alternativa para a própria manutenção do Estado Nação e da democracia, conceitos amplamente questionados diante do importante contexto atual, no qual a informação e a atualidade reinam absolutas.

Portanto, ainda que o cosmopolitismo possua algumas dificuldades para se concretizar e ser aplicado no atual contexto internacional, tem-se que constrói um cenário repleto de oportunidades para a internacionalização e proteção de direitos fundamentais ao ser humano, sendo que, se hoje o mais importante é a instantaneidade da informação obtida, este ideal, apesar de milenar, ainda possui grande valor 
para agregar a humanidade.

\section{REFERÊNCIAS}

APPIAH, Kwame Anthony. La ética de la identidad. Buenos Aires: Katz, 2007 - b. APPIAH, Kwame Anthony. La ética en un mundo de extraños. Madrid: Katz Editores, $2007-\mathrm{a}$.

BECK, Ulrich. La mirada cosmopolita o la guerra es La paz. Barcelona: Paidós, 2005.

CARVALHO, Luiz Gustavo Grandinetti Castanho de. Liberdade de Informação e o direito difuso à informação verdadeira. Rio de Janeiro: Renovar, 2003.

DINUCCI, Aldo. Diógenes, o cão: imagens, ditos célebres, comentários,

Epigramas. Prometeus Filosofia em Revista. Viva Vox - Dfl - Universidade Federal de Sergipe. $n^{\circ} .5$, p. 85-99, 2010. Disponível em: <http://seer.ufs.br/index.php/ prometeus/article/download/752/630>. Acesso em: 15 jan. 2013.

GONÇALVES, Maria Eduarda. Direito da Informação: novos direitos e formas de regulação na sociedade da informação. Coimbra: Almedina, 2003.

HELD, David. La democracia y el orden global. Del Estado Moderno al gobierno cosmopolita. Barcelona: Paidós, 1997.

HELD, David. A democracia, o estado-nação e o sistema global. Lua Nova, São Paulo, n. 23, p. 145-194, 1991. Disponível em: <http://www.scielo.br/scielo.php?script=sci_arttext\&pid=S0102-64451991000100010\&lng=en\&nrm=iso $>$. Acesso em: 05 Jan. 2014.

HOFFE, Otfried. A democracia no mundo de hoje. São Paulo: Martins Fontes, 2005.

KANT, Immanuel. À paz perpétua. Porto Alegre: L\&PM, 2010.

LEAL, Rogério Gesta. A difícil relação entre o direito fundamental à informação e o acesso aos documentos produzidos pelo regime militar brasileiro in Revista de Direito Brasileira, RDBras. Ano 1, 1, Julho-Dezembro de 2011. Coord. Vladmir Oliveira da Silveira.

LÉVY, Pierre. Ciberdemocracia. Tradução de Alexandre Emílio. Lisboa: Instituto Piaget, 2002.

LIMBERGER, Têmis. Cibercidadania no Mundo Globalizado: as novas tecnologias e a concretização dos direitos humanos. In: MORAIS, José Luís Bolzan de; 
COPETTI NETO, Alfredo (org). Estado e Constituição: a internacionalização do Direito a partir dos Direitos Humanos. Ijuí: ed. Unijuí, 2013.

LIMBERGER, Têmis. $\mathrm{O}$ direito à intimidade na era da informática: a necessidade de proteção dos dados pessoais. Porto Alegre: Livraria do Advogado, 2007.

MATTON, Sylvain. Cinismo e cristianismo da Idade Média ao Renascimento. In: GOULET-CAZÉ, Marie Odile. BRANHAM, Bracht R. (org). Os cínicos. O movimento cínico na antiguidade e seu legado. São Paulo: Loyola, 2007.

MENDEL, Toby. Liberdade de informação: um estudo de direito comparado. 2.ed. - Brasília : UNESCO, 2009. Disponível em: <http://www.acessoainformacao. gov.br/acessoainformacaogov/ publicacoes/liberdade-informacao-estudo-direitocomparado-unesco.pdf>. Acesso em: 27 jun. 2013.

MILL, John Stuart. Sobre a Liberdade. Tradução Pedro Madeira. Ed. Especial. Rio de Janeiro: Nova Fronteira, 2011.

MOLES, L. John. Cosmopolitismo cínico. In: GOULET-CAZÉ, Marie Odile. BRANHAM, Bracht R. (org). Os cínicos. O movimento cínico na antiguidade e seu legado. São Paulo: Loyola, 2007.

MORAIS, José Luis Bolzan de; SALDANHA, Jânia Maria Lopes; VIERA, Gustavo Oliveira. O constitucionalismo e a Internacionalização dos Direitos Humanos. In: MORAIS, José Luís Bolzan de; COPETTI NETO, Alfredo (org). Estado e Constituição: a internacionalização do Direito a partir dos Direitos Humanos. Ijuí: ed. Unijuí, 2013.

NEVES, Marcelo. Transconstitucionalismo. São Paulo: Martins Fontes, 2009.

NOUR, Soraya. Os cosmopolitas: Kant e os "temas kantianos" em relações internacionais. Contexto internacional. Rio de Janeiro, v. 25, n. 1, jan/jun. 2003. P. 7-46. Disponível em: <http://www.scielo.br/scielo.php?script=sci_arttext\&pid=S0102$85292003000100001 \& \operatorname{lng}=\mathrm{en} \& \mathrm{nrm}=\mathrm{iso}>$. Acesso em: 20 set. 2013.

ONU. Declaração Universal Dos Direitos Humanos, de 10 de dezembro de 1948. Disponível em: <http://unicrio.org.br/img/DeclU_D_HumanosVersoInternet.pdf>. Acesso em 08 dez. 2013.

PÉREZ LUÑO, Antonio Enrique. Derechos humanos, Estado de Derecho y Constitución. 10 ed. Madrid: Tecnos, 2010.

SALDANHA, Jânia Maria Lopes. Os desafios do "império cibernético" na era da aceleração e da informação: um "sexto continente" de liberdade perfeita ou de controle perfeito? In: TYBUSCH, Jerônimo Siqueira; ARAUJO, Luiz Ernani Bonesso de.; SILVA, Rosane Leal da. (org.). Direitos Emergentes na Sociedade Global: Anuário do Programa de Pós-graduação em Direito da UFSM. Ijuí: Unijuí, 2013. P. 173-219. 
SALDANHA, Jânia Maria Lopes. Os desafios do processo e da jurisdição frente aos processos de integração: rumo a efetivação dos direitos humanos. Novos Estudo Jurídicos (UNIVALI), v. 15, p. 346-361, 2011.

SANTOS, Paloma Maria; BERNARDES, Marciele Berges; ROVER, Aires José. Teoria e prática de governo aberto: lei de acesso à informação nos executivos municipais da região sul. Florianópolis: Fundação Boiteux, 2012.

SEN, Amartya. Ideia de Justiça. Tradução de Denise Bottmann e Ricardo Doninelli Mendes. São Paulo: Compania das Letras, 2011.

SOUZA, Carlos Aurélio Mota de. O Cidadão, a Sociedade, a Mídia e a Justiça. Direito à Privacidade - coord. Ives Gandra Martins Filho, Antônio Jorge Monteiro Junior - Aparecida, SP. Ideias \& Letras; São Paulo, Centro de Extensão Universitária, 2005.

STRECK, Lenio Luiz; MORAIS, José Luis Bolzan de. Ciência Politica e Teoria Geral do Estado. 5 ed. Porto Alegre: Livraria do Advogado, 2006. 